\title{
The Governmental Regulation No. 2 of 2020 and the Head of the Region General Election in the Pandemic ERA: Between the Health Protocol and Cluster Disaster of the Regional General Election
}

\author{
Nofi Sri Utami ${ }^{1}$, Kuswanto ${ }^{2}$ \\ ${ }^{1}$ Lecturer, Faculty of Law, Universitas Islam Malang, ${ }^{2}$ Associate Professor, Universitas Darul Ulum Jombang, \\ Jalan Mayjen Haryono Gang 10 No. 193, Dinoyo, Kec. Lowokwaru, Malang,
}

\begin{abstract}
Objective: The organization of the regional general election during the Covid-19 pandemic surely creates threats towards the citizens' right to live, which is guaranteed by the constitution. It is not easy to guarantee the safety of the organizers as well as the voters and to build a discipline in running the health protocol during the regional general election This paper aims to describe such condition.
\end{abstract}

Method: This research uses the juridical-normative method with the descriptive-qualitative approach.

Result: There needs to be a tight and a measured health protocol which is able to prevent the turning of the regional general election into an arena of mass Covid-19 infection. It is important to strengthen the regulation in the form of prohibitions and sanctions in violating the protocol.

Conclusion: The General Election Commission and the government must act strictly to every violation of the health protocol, as it endangers many people. There must be clear regulations on the prohibition of the general election campaign and activities which involve many people in the red areas, and campaign limitations in the green areas.

Keywords: Election, regional head, pandemic, health protocol.

\section{Introduction}

The global spread of the coronavirus disease (Covid-19) has significantly increased from time to time. Indonesia is also one of the countries which has been impacted by this pandemic. Considering the dangers of this disease, through the mandate stipulated in Article 12 of the Republic of Indonesia's Constitution, the President has issued the Decree of the Republic of Indonesia

\section{Corresponding Author:}

\section{Nofi Sri Utami}

Lecturer, Faculty of Law, Universitas Islam Malang, Jalan Mayjen Haryono Gang 10 No. 193, Dinoyo, Kec. Lowokwaru, Malang
President No. 11 of 2020 regarding the Determination of a Health Urgency. Referring to the analysis of an urgent law of governance, the determination of this urgent condition is still in the staatsnoodrecht scope, where the state is obliged to issue some policies to face the urgent situation. The implementation of that policy is written in the Large-Scale Social Restrictions in the form of restrictions which have started to be implied and suggestions to avoid activities which involve many people. Recently, the government has applied the policy against homecoming during great religious celebrations to cut the chain of the covid-19 pandemic infections.

Even though it brings many critics, the government has decided to organize the Regional General Election on December $9^{\text {th }}, 2020^{1}$. It means that this event, which is organized once every five years, will be organized 
during the Covid-19 pandemic. The Regional General Election stages which were beforehand stopped due to the Covid-19 pandemic have now been continued. Article $8 \mathrm{~B}$ of the Regulation of the General Election Commission No. 5 of 2020 states explicitly states that, "Execution of the simultaneous voting which was before postponed due to the non-natural disasterof the CoronaVirus Disease 2019 (Covid-19), will be carried out on December 9 $9^{\text {th }}$, 2020". This Regulation of the General Election Commission is an explanation of the order of Article 201A clause (2) of the Governmental Regulation in Change of the Constitution No. 2 of 2020, which states that, "Execution of the simultaneous voting which was before postponed as mentioned in clause (1) will be carried out on December $2020^{2}$.

Based on the data from International IDEA (Institute for Democracy and Electoral Assistance), during the period from February $21^{\text {st }}$ to July $19^{\text {th }} 2020$, there were at least 67 countries and territories in the whole world which decided to postpone national and sub-national general elections due to the Covid-19 pandemic. From this number, at least 23 countries decided to postpone national general elections and referendums. On the same period, 49 countries and territories have decided to execute the organization of national or regional general elections as planned beforehand, From the 49 countries which organized those general elections during the pandemic, there are of course stories which may be extracted and turned into valuable lessons.

The countries which still choose to organize the general elections during the Covid-19 pandemic had experienced many challenges. One of the most difficult challenge is "the responses of the citizens" who are voters in those elections. There is the risk of a Covid-19 infection to the citizens, which is a main consideration which must be answered by the government. The state, through the government, must give a guarantee of safety to their citizens, so that the suffrage rights may be carried out safely and comfortable. The government must make sure that the head of the region general elections will not be a place where the coronavirus disease spread to the citizens with the clusters of the heads of the region elections. Because of that, the General Commission of the General Election (KPU) chooses to decrease the target of the voter participation ratein the heads of the region elections ${ }^{3}$.

\section{Table 1: Participation Rate of Voters in Countries of Territories which Conducted an Election during the} Pandemic

\begin{tabular}{|c|l|l|c|c|c|}
\hline No. & Country & Type of Election & Execution Date & Participation Rate & Previous Election Rate \\
\hline 1 & Iran & Parliamentary & February $21^{\text {st }}, 2020$ & $42,32 \%$ & $60,09 \%$ \\
\hline 2 & Dominica Republic & Presidential & March $15^{\text {th }}, 2020$ & $55,18 \%$ & $67,77 \%$ \\
\hline 3 & Vanuatu & Parliamentary & March $19^{\text {th }}, 2020$ & $51,29 \%$ & $56,47 \%$ \\
\hline 4 & Guinea & Parliamentary & March $22^{\text {nd }}, 2020$ & $58,04 \%$ & $63,53 \%$ \\
\hline 5 & Queensland, Australia & Local General Election & March $29^{\text {th }}, 2020$ & $77-78 \%$ & $83 \%$ \\
\hline 6 & Mali & Parliamentary & March $29^{\text {th }}, 2020$ & $35,58 \%$ & $38,50 \%$ \\
\hline 7 & South Korea & Parliamentary & April $15^{\text {th }}, 2020$ & $66,21 \%$ & $58,03 \%$ \\
\hline 8 & Serbia & Parliamentary & June $21^{\text {st }}, 2020$ & $48,93 \%$ & $56,07 \%$ \\
\hline 9 & Iceland & Presidential & June $27^{\text {th }}, 2020$ & $66,92 \%$ & $75,67 \%$ \\
\hline 10 & Croatia & Parliamentary & July $5^{\text {th }}, 2020$ & $46,90 \%$ & $52,59 \%$ \\
\hline 11 & Singapore & Parliamentary & July $10^{\text {th }}, 2020$ & $95,81 \%$ & $93,70 \%$ \\
\hline 12 & Poland & Presidential & July $12^{\text {th }}, 2020$ & $68,18 \%$ & $55,34 \%$ \\
\hline
\end{tabular}

Source: International IDEA

In some other states, there is a decrease of the participation rate of the election when organized during the Covid-19 pandemic. These countries are Iran,
Dominica Republic, Vanuatu, Guinea, Mali, Serbia, Iceland, and Croatia. In Iran, the voter participation rate was only $42,32 \%$ from the total of $57,918,000$ 
registered voters. On the previous general election on 2016, the voter participation rate in Iran reached 60,09 $\%$. A similar thing also happened in Serbia, where the level of voter participation only reached $48,93 \%$ from the total of $6,584,376$ registered voters. On the previous general election on 2016, the voter participation rate reached $56.07 \%$. Even though the majority of countries experienced a decrease in the participation rate, there are also other countries which experience an increase, which are South Korea and Poland ${ }^{4}$.

This data means that the Indonesian government and the KPU must work hard to increase the general election participation even though they are faced with the risks of the pandemic. It is not easy to guarantee the health of the organizers as well as the voters. There needs to be a strict health protocol which may make sure that the head of the region general election does not become an arena of mass Covid-19 infection.

\section{Materials and Method}

This paper uses the juridical-normative research method. The approach used in this research is the descriptive-qualitative approach ${ }^{5}$. This means that this research describes how the regional general election will be during the pandemic, where the organizers must fulfil a tight health protocol, so that a cluster health disaster during the election may be prevented.

\section{Results and Discussion}

The local-level participation of the people is a manifestation of desire and application of the people's sovereignty principle which hopes for a real impact in creating an output, which is to create a new government ${ }^{6}$. The effort to create a new government in the various regions of Indonesia actually manifests a spirit of nationalism and high hope. But the government and the Indonesian society have an awareness in reading the situation which is happening, where the Covid-19 pandemic is a main problem which must be wisely reacted upon. The relation between the society and the government may be said as a synergy to go through these hard times in the 2020 political contest ${ }^{7}$. In this urgent condition due to the Covid-19 pandemic, all political maneuvers and mechanisms become riskier. The political actors must also have their own strategies to keep on directing the mass, because the aim is to win the competition.
Even if the choice of organizing the election of 2020 becomes optional, the consideration of the legal processes and results must be able to be described in a technique which is easily understood by all parties. This is because the loss experienced by the participants and the voters due to an uncommon technique may cause a long-term problem. Moreover, a great legal consequence may haunt the general election organizers.

Because of that, by issuing the Governmental Regulation in Change of the Constitution No. 2 of 2020, the government is thought to have created an amazing policy. It may be said as too brave. This is because this statement of optimistic law will be written in history. This Governmental Regulation in Change of the Constitution on the Regional General Election also places itself as a legal innovation. This Governmental Regulation is created due to the extreme condition which happens; thus, the head of the region general election must still run in the middle of the pandemic.

One on hand, in the political point of view, the execution of the 2020 general election is a water spring in the dry season of the pandemic's era of uncertainty. The general election organization (KPU) answers all political efforts of the head of the region candidates. Because of that the prospecting election participants may decrease the excessive expenditures during the pandemic. On the other hand, there is the potential of a lawsuit on the organization technique, which may enter the arena of law enforcement. It is complicated and confusing and also the law during the pandemic is extraordinary law if the government want the regional election not became a disaster.

The organizers must be able to execute the election. It is no secret that the funding money becomes the main problem in organizing an election. If the fund is not enough due to economic policies in handling the Covid-19, there is a risk of a cut of funds for the election, which may decrease the performance quality. The choice to still organize the regional general election must be supported by giving a special budget without decreasing it for any reason ${ }^{8}$.

To develop a discipline in running the health protocol during the regional general elections, it is crucial to strengthen the regulations in the forms of prohibitions and sanctions to the violation of those protocols. Unfortunately, this simultaneous regional general election still uses the regulatory design which 
is only applicable during normal conditions. It cannot be applied during an abnormal condition due to the pandemic. Because of that, the prohibitions and sanctions to the violation of the health protocols are not regulated in the regional general election regulations. Meanwhile in Indonesia, we have not yet had enough experiences in organizing an electoral process during an urgent situation ${ }^{9}$.

The point is that the regional KPU during the Covid-19 pandemic should not threaten the life of the citizens. Thus, the management of this simultaneous regional general election must be directed to fulfill the standard protocol in saving the human lives. Because principally, the regional general election is for the sake of the human beings, and not the other way around.

Practically, the KPU has noted 243 alleged cases of health protocol violation during the registration process of head of the region prospective pair of candidates which happened for three days. During the registration process, the prospective pairs of candidates were escorted by masses of supporters which causes the occurrence of crowds and has the potential to spread the coronavirus disease. Before that, President Joko Widodo has asked the Minister of Internal Affairs and the KPU to strictly monitor and act upon the parties who violate the health protocol during the regional democratic celebration to prevent the spread of the coronavirus disease and to prevent the occurrence of regional general election clusters ${ }^{10}$.

Based on the data of the Ministry of Internal Affairs, there were 733 prospective pairs of candidates whose registration applications were accepted. Among them, 294 prospective pairs of candidates were incumbent. Based on the data from the Ministry of Coordinator in the Politic, Law, and Human Rights, Mahfud MD, until Wednesday afternoon (September $\left.9^{\text {th }}, 2020\right)$, there were 59 prospective pairs of candidates from that number who were confirmed to be positive of the Covid-19 disease, which were spread in 21 provinces. The General Election Commission stated that, even though they were tested positive of the Covid-19 disease, those prospective pairs of regional head candidates will not lose their position as candidates ${ }^{11}$.

The KPU is optimistic that the election will be organized well if four main requirements are met. First, the legal certainty framework must be strengthened before starting the stages. As known before, the Governmental
Regulation in Change of the Constitution No. 2 of 2020 , the General Election Commission Regulation No. 5 of 2020 on the Stages, Schedules, Programs, and the Decree of the KPU the regional general election execution during the Covid-19 pandemic has been officially released.

The problem which arises is the threat towards the people's safety and health if the 2020 Regional General Election will still be organized. This will risk the people as the constituents, the participants who are the pairs of candidates and the regional general election organizers who are the KPU and its team. Not only that, the quality degradation of the election organization stages which will be carried out during the Covid-19 pandemic may cause malpractices in its establishment process, starting from the voter data update, the independent candidate requirement of support verifications, campaigns, and the voting process. ${ }^{12}$.

The current problems which arrive due to the Covid-19 become universal and basic problems. On the other hand, the government and the related institutions persist to start the 2020 Regional General Election contest on December $9^{\text {th }}$. So far, Indonesia has not experienced a period of regional general election execution with the threat of a pandemic which has the high potential in influencing the health of the people and which may even cause death ${ }^{13}$. The General Election organizers, especially the KPU must maximally apply the health protocols. They must also prepare adequate supporting equipment to be used in the field, such as personal protective equipment, hand sanitizers, disinfectant sprays, masks, soap, sinks to wash hands, sterilized voting booths, etc. The Regional Governments must increase their awareness towards the symptoms and the spread of the Covid-19 disease in their areas by preparing health facilities and health worker to handle unwanted occurrences.

\section{Conclusion}

Even though it attracts many critics, the Regional General Election has been determined to be established on December $9^{\text {th }}, 2020$. This means that this event which is held every five years will be organized during the Covid-19 pandemic. The initial stage of the Regional General Election process has produced more than 200 violations of health protocol, which causes a fatal impact, as 59 person of head of the region candidates were diagnosed as Covid-19 positive. 
The General Election Commission and the government must act strictly to every violation of the health protocol, as it endangers many people. There must be clear regulations on the prohibition of the general election campaign and activities which involve many people in the red areas, and campaign limitations in the green areas. The government must increase the budget to prepare health protocol facilities such as personal protective equipment, hand sanitizers, disinfectant sprays, masks, soap, sinks to wash hands, sterilized voting booths, and other hygienic equipment to protect the public and the regional general election officials from the Covid-19.

\section{Conflict of Interest: No}

\section{Source of Funding: Author}

\section{Ethical Clearance: Yes}

\section{References}

1. Kabar 24 Bisnis. This is the newest and most complete simultaneous regional general election 2020. 2020 Jun 24. Available from https://kabar24. bisnis.com/read/ 20200624/15/1257129/inijadwal-lengkap-tahapan-pilkada-serentak-2020terbaru

2. Hamzah $\mathrm{H}$. The regional general election versus the pandemic and experiences of other countries. Paper presented at: The Tendency on the Misuse of Power in the Regional General Election; 2020 Aug 11; Samarinda, Indonesia.

3. Monarqi AP. A regional general election during the pandemic, the general election commission decreases the voter participation target to 77,5 percent. Kompas.com. 2020 Jun 4. Available from: https://nasional.kompas.com/ $\mathrm{read} / 2020 / 06 / 04 / 16330941 /$ pilkada-saat-pandemikpu-kurangi-target-partisipasi-pemilih-jadi-775persen?page $=$ all.

4. Spinelli A. Organizing the general election during the covid-19 pandemic: a crucial test of the Republic of Korea. In: Technical Magazine of International IDEA; 2020 Mar. International Institute for Democracy and Electoral Assistance (International IDEA). https://doi.org/10.31752/idea.2020.17
5. Utami NS, Prasetyoningsih N, Hidayat A, Huda N, Suteki S, Saraswati R, BudionoA. Equality of the Political Rights of People with Mental Disorders (PWMD) in General Elections. Indian J of Forensic Medicine \& Toxicology. 2019;13(4):1572.

6. Arifulloh A. Execution of the simultaneous regional general election which is democratic, peaceful, and dignified. J Pembaharuan Hukum. 2015;2(2):301311.

7. Buana DR. Analysis of the Indonesian people's behaviors in facing the coronavirus pandemic (covid-19) and the tricks in maintaining the psychological health. Salam: J Sosial dan Budaya Syar-i. 2020;7(3).

8. Hasibuan R. Urgency of the regional general election governmental regulation in change of the constitution during the covid-19 pandemic. ADALAH: Buletin Hukum dan Keadilan. 2020;4:121-128.

9. Habibi A. The efforts to save the general election on 2020. Adalah: Buletin Hukum dan Keadilan. 2020;4:167-172.

10. Firmansyah R. Perludem states that the simultaneous regional general election during the pandemic is unwise). Pikiran Rakyat. Available from : https://prfmnews.pikiranrakyat.com/nasional/ pr-13396213/perludem-sebut-pilkadaserentak-ditengah-pandemi-terlaludipaksakan? page $=2$

11. BBC. The regional general election 2020: hundreds of alleged healh protocol violations, observers call for 'total evaluation or postponement'). BBC [Internet]. Available from: https://www.bbc.com/ indonesia/indonesia-54069686

12. Rizki SC, Hilman YA. Measuring the different opinions in the agenda of the regional general election contest execution during the covid-19 pandemic. J Ilmiah Muqodimah. 2020;4(2):145.

13. Sari PH. Electoral distancing: an alternative in running the regional general election 2020 during the covid-19 pandemic in Indonesia. J Magistrorum et Scholarum. 2020;1(1):113-114. 